\title{
Researches Concerning Chemical Modifications of Hair Keratin
}

\begin{abstract}
VASILE CIPRIAN MACAREL ${ }^{1}$, CEZAR DORU RADU1*, LILIANA VERESTIUC ${ }^{2}$, FLORINA DANIELA IVAN ${ }^{2,3}$, EUGEN ULEA4, FLORIN LIPSA ${ }^{4}$, MIHAELA ANDREEA FLOREA ${ }^{4 *}$, IOAN EMIL MURESAN ${ }^{3}$, CAMELIA TAMAS $^{6}$, CRISTINA PIROI ${ }^{1}$, CORNELIU MUNTEANU 6

${ }^{1}$ Gheorghe Asachi Technical University of Iasi, Faculty of Textile, Leather Engineering and Industrial Management, 29 Mangeron Str., 700050, Iasi, Romania

${ }^{2}$ Grigore T.Popa University of Medicine and Pharmacy, Department of Medical Bioengineering, 11-16 M. Kogalniceanu Str., 700454, Iasi, Romania

${ }^{3}$ Gheorghe Asachi Technical University, Faculty of Chemical Engineering and Environmental Protection, 73 Mangeron Str., 700050, Iasi, Romania

4..Ionescu Brad University of Agricultural Sciences and Veterinary Medicine, Department of Plant Sciences, 3 M.Sadoveanu Alley, 700490, lasi, Romania

${ }^{5}$ Grigore T.Popa University of Medicine and Pharmacy, Department of Plastic Surgery, 16 Universitatii Str., 700115, lasi, Romania ${ }^{6}$ Gheorghe Asachi Technical University of lasi, Faculty of Mechanics, 61-63 Mangeron Str., 700050, lasi, Romania

The work presents chemical procedures used to obtain a film or a hydrogel after hydrolyze treatment of hair at the temperature of $150^{\circ} \mathrm{C}$ and the pressure of $4.9 \mathrm{~atm}$. In order to obtain the hydrogel, this treatment is followed by a stage of oxidation with hydrogen peroxide, and a stage of reduction with $\mathrm{Na}_{2} \mathrm{~S}_{2} \mathrm{O}_{4}$ or, in another variant, a stage of oxidation with hydrogen peroxide and a treatment with $\mathrm{NaOH}$ in alcoholic medium, to form natrium cationic groups. The protein chains with sulphonic groups and natrium cations determine opposite electrostatic interactions, with the formation of a polymer loop that incorporate water. The evaluation of formed hydrogel was carried out by determining the swelling degree. We have used optical and SEM photomicrographs to determine morphological organization, and EDAX micropictures for chemical modifications. A cellulose film realized by growing Gluconoacetobacter xylinus bacteria was used as control sample.
\end{abstract}

Keywords: beta-keratose, gamma-keratose, hydrogel, film

Loosing the skin function due to a lesion or a disease determines a severe unbalance and a physiological incapacity that can be lethal. Skin substitutes manufactured in tissues have their limits related to clinical utilization. In this field of specialization, there is no therapeutic tissue substitute able to take over skin function through a sole procedure, and with an adequate thickness for a corresponding coating of thick wound [1].

In order to obtain material support, in medical applications one uses natural polymers, such as keratin which, by their biological and physico-chemical properties, transfer these properties to the designed materials [2-5]. Regardless its origin, keratin presents scientifically substantiated morphological details that needed over time special cognition efforts. The evolution of the understanding of structural details and the role played in fiber biology has as aiming points some reference names such as: Elod E., Speakman father and son, Zahn $\mathrm{H}_{\text {., }}$ but there are also structural details for which the scientific research continues [6]. The utilization of keratin hydrogel offers the biomaterial the possibility of a controlled drug release, as well as its utilization as a support for building the artificial skin $[7,8]$.

In the case of burnt wounds with a wide surface of the affected skin, there is a complex of factors that strongly affect the general patient condition. Namely, the severe burns determine destructions of skin and of other deep structures, with homeostasis (organism natural selfregulation) alteration, by maintaining the biochemical parameters within constant limits). Depending on the duration of heat aggression, it can result in enzymatic process alteration, protein necrosis, tissue caramelization and calcination.

The above mentioned phenomena are accompanied by diminution or loss of body capacity to maintain the heat and to preserve biologic fluids, with the severe alteration of circulatory, hepatic and renal functions, against a generalized sepsis. The wound evolution determines frequently an additional loss of derma tissue [9]. In literature, there are communications regarding cell proliferation in the burnt wounds. These communications refer to collagen or keratin biomaterials [10], factors of cell regeneration intensification [11,12] , or cell engineering procedures [1].

The connection between keratin and skin regeneration is related to a tradition from the history of civilization, according to which, in order to cure the burnt wound, one needs to burn some of patient hair; the resulting solid mass in crushed and transformed in a powder, remedy for patient wound. In literature there are approaches related to the production of keratin-based biomaterials [13]. Besides the surgical and pharmaco-dynamic therapy, for the amelioration of patient general condition, it is imperiously necessary to solve the problem of skin deficit for wounds' coating self-grafting. It has been mentioned that their limitation can be compensated by producing teguments through tissue engineering techniques.

The work presents the possibility of chemical keratin processing from patienthuman hair, to obtain a biomaterial under the form of hydrogel or film, destined to tissue growth with prospective to be used as skin substitute, in order to avoid immunity reactions.

Considerations on human keratin utilization as biomaterial Human hair is a keratin fiber developed from skin follicle, having the role of protection agent, sensor and sexual attraction, being a characteristic common to both man and mammals. The human hair structure is chemically and morphologically similar to the sheep wool. The difference consists in the fact that for wool, the ortho-para structure is differentiated, with cell disposition under the form of two bands twisted along the fiber $[14,15]$. Keratin

\footnotetext{
* email: dcradu@tex.tuiasi.ro; balau_andreeea@yahoo.com
} 
products are biocompatible mediums that facilitate the cell growth [5].

\section{Experimental part}

One has collected undyed hair, cut at lengths of $2-5 \mathrm{~cm}$, from men regardless the age, delivered by a hair dresser; then the collected hair was cleaned for $24 \mathrm{~h}$, in a Soxhlet by removing the lipids, using a mixture of $\mathrm{CHCl}_{3}$ and $\mathrm{CH}_{3} \mathrm{OH}$ in ratio of $2: 1(\mathrm{v} / \mathrm{v})$. The hair is dried by night at $40^{\circ} \mathrm{C}$. The cleaned hair and an amount of distilled water are introduced in a sealed stainless steel capsule, at a solid/ liquid ratio of 2:35 (w/w). The capsule is introduced in an air-drier at $150^{\circ} \mathrm{C}$ for $2 \mathrm{~h}$, as illustrated in figure 1 .

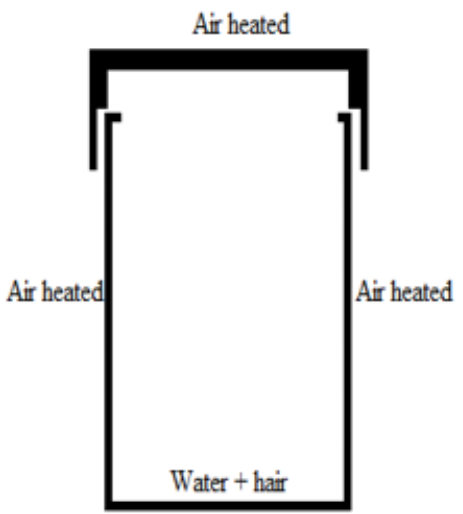

Fig. 1. Scheme of hydrolytic hair treatment device

Inside the capsule at $150^{\circ} \mathrm{C}$, a water vapor pressure of 4.9 at. (about $48 \cdot 10^{4} \mathrm{~Pa}$ ) is developed, according to Pavlov [16].

After treatment, two phases were separated through centrifugation for 10 min at 10,000 rpm, namely: a solid phase insoluble in water, considered as beta-keratose, and a liquid water-soluble phase, gamma-keratose.

\section{Beta keratose film}

In order to prepare the beta-keratose film, the material is subjected to a oxidation treatment with hydrogen peroxide, $3 h$, using atboiling $4 \mathrm{~g}$ solid phase and $\mathrm{H}_{2} \mathrm{O}_{2}(30 \%)$ at a ratio of 1:4 (w/v). The obtained solid phase is filtered and washed with $100 \mathrm{ml}$ distilled water, by 6 times. It is dried for $24 \mathrm{~h}$ at $40^{\circ} \mathrm{C}$. Then, a reduction process follows, using $\mathrm{Na}_{2} \mathrm{~S}_{2} \mathrm{O}_{4^{\prime}}$ added in 6 equal portions of $0.3 \mathrm{~g}$ each, in beta-keratose emulsion, at one hour intervals each, at $72^{\circ} \mathrm{C}$. This is followed by solution cooling and its deposition on bacterial cellulose mass, and by lyophilization. The cellulose is in the form of a nanofiber veil, obtained by seeding Gluconobacter xylium.

\section{Gamma keratoze film}

The liquid water-soluble gamma-keratose phase obtained from the hair subjected to a hydrolytic process at $150^{\circ} \mathrm{C}$ is deposited over the bacterial cellulose film.

\section{Hydrogel 1}

In order to obtain the hydrogel from beta keratose film according to procedure 1, after cooling the solution, the supernatant is extracted through centrifugation at 10000 rpm for $10 \mathrm{~min}$. The obtained solution is cooled and additionally oxidized with $4 \mathrm{~mL} \mathrm{H}_{2} \mathrm{O}_{2}$ for 10 min, repeating the procedure 6 times. Then the solution remains for $72 \mathrm{~h}$ at room temperature. The solution gets slowly thicker, forming a cross-linked gel.

\section{Hydrogel 2}

Beta-keratose is subjected to an oxidation treatment with boiling hydrogen peroxide for $3 \mathrm{~h}$, using $4 \mathrm{~g}$ solid phase and $\mathrm{H}_{2} \mathrm{O}_{2}$ at a ratio of $\mathrm{l}: 4(\mathrm{w} / \mathrm{v})$. Then it is washed with $96 \%$ ethanol and squeezed by pressing with filter paper, treated with $18 \mathrm{ml}$ of $96 \%$ ethanol with a content of $\mathrm{NaOH}$ reported to keratose quantity of $0.14: 2(\mathrm{w} / \mathrm{w})$ to obtain a $\mathrm{pH}=8.5$ 9. It is treated at $98^{\circ} \mathrm{C}$ for $3 \mathrm{~h}$ and then stirred cooled for $5 \mathrm{~h}$. It is then detached from filter paper and washed six times with $100 \mathrm{ml}$ distilled water. One obtains a hydrogel consisting of swollen hair filaments.

Hydrogel characteristics

Swelling degree

The swelling degree is evaluated in percentages, based on gravimetric tests:

$$
\operatorname{SD}(\%)=\left(M_{f}-M_{i n}\right) \times 100 / M_{\text {in }}
$$

where: $M_{f}$ - weight of material after swelling, $M_{\text {in }}$ - weight of the initial (dry) material.

In the case of performed determinations, the initial mass of beta-keratose subjected to treatment was 2 grams.

Table 1 presents the swelling degree values obtained through gravimetric measurements in the two cases of hydrogel.

\section{Elemental composition determinations}

Chemical composition of the elements was determined in percentages through EDAX technique. The obtained data are summarized in table 2 .

Here the witness samples are the bacterial cellulose film, while the beta- and gamma-keratose hydrogel samples are lyophilized films.

\section{Morphological aspects}

For morphological visualizations, one has prepared the following biomaterials:

Hydrogel 1 is illustrated in figure 2, witness sample consisting of bacterial cellulose film is presented in figure 3 , biomaterial consisting of cellulose film and betakeratose is illustrated in figure 4, while figure 5 presents the biomaterial consisting of bacterial cellulose and gamma-keratose film, and figure 6 represents a micrograph of hydrogel 2 after drying.

\begin{tabular}{|l|l|l|l|l|}
\hline No. & Mf(g) & Mm (g) & $\begin{array}{l}\text { Swelling } \\
\text { degree } \%)\end{array}$ & $\begin{array}{l}\text { Swelling average } \\
\text { degreee (\%) }\end{array}$ \\
\hline \multirow{3}{*}{ Hydrogel 1 } & 12.11 & 4.00 & 202.75 & \multirow{2}{*}{211.59} \\
\cline { 2 - 4 } & 13.90 & 4.03 & 244.91 & \\
\cline { 2 - 4 } & 11.21 & 3.9 & 187.43 & \multirow{3}{*}{590.44} \\
\hline \multirow{3}{*}{ Hydrogel 2 } & 27.9 & 4.12 & 577.18 & \\
\cline { 2 - 4 } & 27.20 & 4.0 & 580.25 & \\
\cline { 2 - 4 } & 26.99 & 3.78 & 614.02 & \\
\hline
\end{tabular}

Table 1

SWELLING DEGREE VALUES IN HYDROGEL CASE

\begin{tabular}{|l|l|l|l|l|l|}
\hline No. & Sample & $\mathbf{C}$ & $\mathbf{N}$ & $\mathbf{O}$ & $\mathrm{S}$ \\
\hline 1 & Control & 47.87 & - & 51.12 & 1.01 \\
\hline 2 & Beta-cheratose & 45.55 & 2.39 & 47.65 & 4.41 \\
\hline 3 & Gamma-cheratose & 50.75 & 2.98 & 41.75 & 4.52 \\
\hline 4 & Hydrogel & 64.93 & 2.18 & 25.70 & 7.19 \\
\hline
\end{tabular}

Table 2

EXPERIMENTAL VALUES OF EDAX ELEMENTAL COMPOSITION 

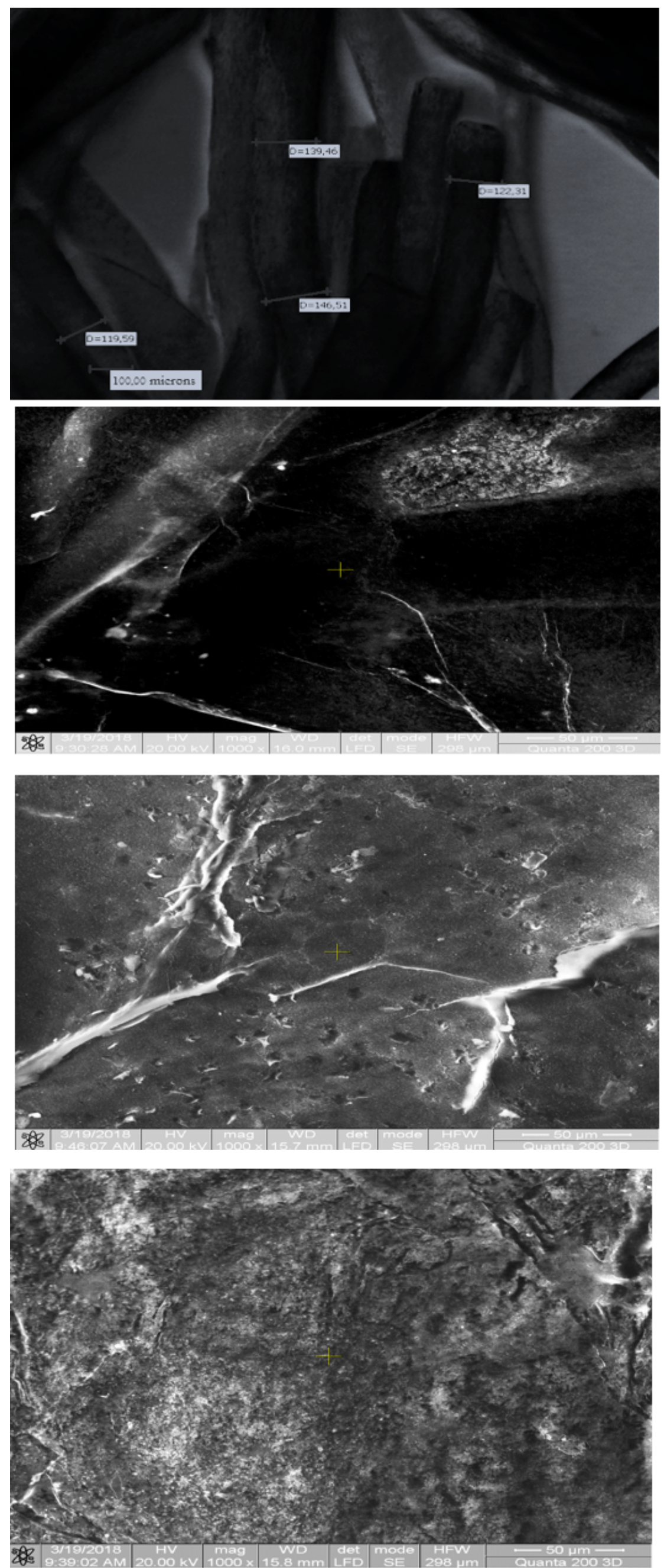

REV.CHIM. (Bucharest) $70 \diamond$ No. $6 \diamond 2019$
Fig. 2 - Optic microscopy image $x 100$ of hydrogel 1 from beta-keratose in wet condition

Fig. 3. SEMx1000 micrograph of witness sample made of bacterial cellulose
Fig. 4. SEMx1000 micrograph of biomaterial consisting of cellulose film and beta-keratose
Fig. 5. SEMx1000 micrograph for the film of bacterial cellulose and gamma-keratose 


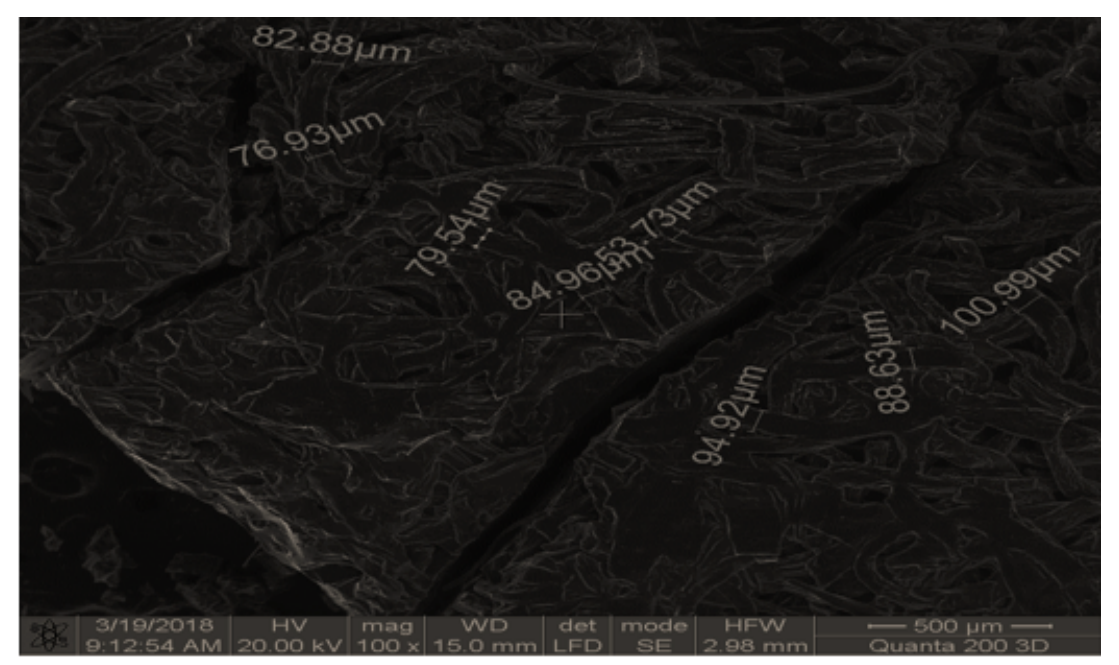

Fig. 6. SEMx1000 micrograph of the hydrogel 2 film

\section{Results and discussions}

Taking into account that the skin represents a human organ with a big surface [17], its regeneration implies a series of peculiarities. According to the opinion of the authors of this study and to other bibliographic references $[2,5]$, keratins preparation with the formation of a biomaterial constitutes a basic sustaining element for artificial tegument realization.

The treatment of hair in the metallic capsule at $150^{\circ} \mathrm{C}$ and pressure of $4.9 \mathrm{~atm}$. in the presence of water determines a hydrolytic process of protein material splitting in two parts: a solid part, considered to be beta-keratose, and a water-soluble phase, namely gamma- keratose $[5,18,19]$.

In the case of the studied hydrogel, one has obtained different swelling degrees, as the result of procedures differences. Under the action of temperature and pressure as common treatment, both procedure participate in hair hydrolytic degradation in the two types of keratose, beta and gamma. This treatment is followed by an oxidative treatment with hydrogen peroxide, which facilitates the splitting of cystine disulphide bonds in sulphonic groups, as illustrated in figure 7 .

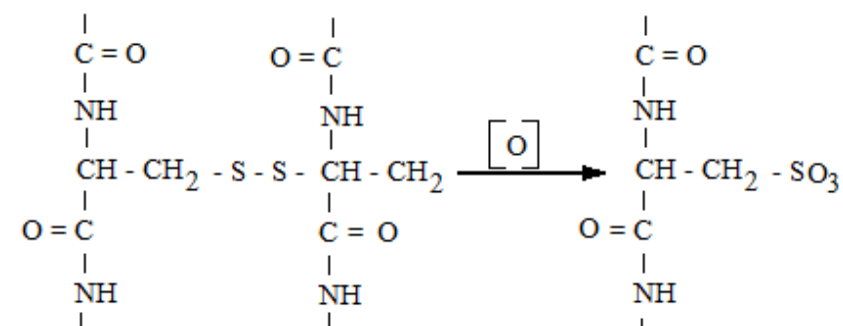

Fig. 7- Oxidation of cistine chains from keratin with the formation of sulphonic derivates

According to figure 7, the oxidation reaction of cystine sulphur is the most probable reaction. Yet, other oxidation reactions are also possible, for instance oxidation of carbonyl derivates to carboxyl derivates, or reaction of cystine oxidation with the preservation of cystine chain and the formation of oxygenated compounds from monoto tetra oxide, or with chain splitting and the formation of cysteine sulphenic or cysteine sulphinic compounds. These oxidations have a low weight and are not important from the standpoint of this work.

The sulphonic groups determine the solubilization of keratin degradation products, and the capacity to interact with an increased number of water molecules, on which they are fixed through hydrogen bonds. The subsequent treatment of reduction with natrium bisulphite results in the unsaturated bonds hydrogenation, generating new compounds, as well as in the possibility to re-form the disulphide bonds and to partially re-stabilize the split fragments. Both, oxidation and reduction treatments are determinative factors in the generation of keratin hydrogel $[18,19]$.In the case of hydrogel 2 , the formation of sulphonic groups with negative charge and the ability to adsorb water molecules represent a determinative factor. Namely, the presence of natrium cations in the reaction system implies electrovalent interactions, with the formation of a stabilized loop between the existing $\mathrm{Na}^{+}$cations and the sulphonic anions from polymer chain, facilitating hydrogel organization [18].

According to the above presented images, one can obtain a hydrogel that follows the organization of the hair in quasi-fibrillary state (images from figs 2 and 6) or of more homogeneous formations (figs.3-5). Depending on keratin treatment and processing procedure, one can obtain more compact (beta-keratin and cellulose) or more porous formations.

According to EDAX data presented in Table 2, where the witness sample is a cellulose structure of bacterial origin, the presence of sulphur in the structure can be exclusively due to Acetobacter xylinum bacteria. For the other representatives illustrated in table 2 , sulphur comes from hair cystine structure, while the nitrogen certifies the protein structure as the result of the presence of constitutive amino acids.

Different oxidation degrees indicate differences at the level of the implied chemical modifications and of keratin sources, from beta-keratin and gamma-keratin respectively.

\section{Conclusions}

The keratin structure of the human hair is susceptible of chemical transformations that permit to obtain a film or hydrogel precursors for the generation of a biomaterial as tegument substitute.

The obtained hydrogel determines the swelling degrees necessary to optimize the preparation factors that compete to hydrogel performance as biomaterial adequate as artificial tegument.

The obtained hydrogels, as well as the cellulose film are precursors for biomaterials meant for tegument regeneration.

\section{References}

1.CHUA, A.W., KHOO, Y.C., CHUA, A.W., KHOO, Y. C., TAN, B. K., TAN, K.C., FOO, C.L., CHONG, SJ ., Burns \& Trauma 4 (3) 2016, p.13.

2.SONGMEI, X., LIN, S., YAPING, Z., XIAOLIANG, W., XUDONG, L., Mater Sci Eng C Mater Biol 33, 2013, p.648. 
3.AKIRA, N, MAKOTO A,KEIJI T. TOSHIHIRO F., Biol Pharm Bull. 25 (5), 2002, p.569.

4.STEFANESCU, D.C., CEACHIR, O., ZAINEA, V., HAINAROSIE, M, PIETROSANU, C., IONITA, I.G., HAINAROSIE, R., Rev Chim. (Bucharest), 67, no.7, 2016, p.1327.

5.DE GUZMAN, R.C., MERRILL, M.R., RICHTER, J.R., HAMZI, R.I., GREENGAUZ-ROBERTS, O.K., VAN DYKE, M.E., Biomater, 32 (32), 2011, p.8205.

6.RADU, C.D., Physics and chemistry of keratins (in Romanian), Publ.House Performantica, lasi, 2003, p. 6.

7.PARTENI, O., RADU, C. D., MURESAN, A., SANDU, A. V., et al., Rev Chim. (Bucharest), 66, no.11, 2015, p.1780.

8.PERALTA RAMOS, M.L., GONZÁLEZ, J.A., FABIAN, L., PEREZ, C.J ., VILLANUEVA, M. E., COPELLO, G.J ., Mater Sci Eng C Mater Biol Appl, 78, 2017, p.619.

9. PORANKI, D., GOODWIN, C., VAN DYKE, M., Bio Med Res Intern, 2016, 2016, p.1.

10. PORANKI, D., WHITENER, W., HOWSE,S., J. Biomater Appl., 29, (1), 2014, p.26.
11. FREYBERG, S., SONG, Y H, MUEHLBERG, F., ALT, E., J Vasc Res, 46, (2), 2009, p.98.

12. OLSZEW SKA-PAZDRAK, B., HART-VANTASELL, A., CARNEY, DH, J.Vasc Res, 47, (3), 2010, p.203.

13. KESKIN, Z., URKMEZ, A S., HAMES, E.E., Mat Sci Eng C, 75, 2017, p.1144.

14. POPESCU, C., Chapter 7 in Physics and Chemistry of Keratins (in Romanian), Publ.House Performantica, Ia'i, 2003, p.175.

15. POPESCU, C., HOCKER, H., Chem Soc Rev., 36, (8), 2007, p.1282. 16. PAVLOV, K.F., .ROMANKOV, P.G. NOSKOV A.A. et al., Processes and apparatus in chemical engineering (in Romanian), Editura Tehnica, edition 8th, 1981, table LVII, p. 529.

17.SONTHHEIMER,R.D., J Invest Dermatol., 134, (2), 2014, p. 581. 18.*** Keraplast Technologies Ltd, Keratin-based hydrogel for biomedical applications and method of production US PATENT 5932552 A

19.*** Keraplast Technologies Ltd, Keratin-based powders and hydrogel for pharmaceutical applications US PATENT 6544548 B1

$\overline{\text { Manuscript received: } 30.10 .2018}$ 